\title{
A study of efficacy and safety of tranexamic acid versus iodopovidone in pleurodesis via pigtail catheter in management of recurrent pleural effusion
}

\author{
Ayman H. Abd El Zaher and Ayman S. El Dib ${ }^{*}$
}

\begin{abstract}
Background: Researches to detect the ideal agent for pleurodesis are still continuous; iodopovidone is one of the best agents for pleurodesis that are commonly used. Tranexamic acid is also considered by many authors as a safe, cheap, and effective agent for pleurodesis.

Results: Group I (patients subjected to pleurodesis using tranexamic acid) had a higher complete response with a success rate $88 \%$ compared with $76 \%$ for group II (patients subjected to pleurodesis using iodopovidone) at the end of the study in 12 weeks. Complications were nearly equal in both groups. Chest pain, hypotension, and fever were the most common reported complications.
\end{abstract}

Conclusions: Tranexamic acid and iodopovidone were found to be effective alternative agents for pleurodesis with low cost and minimal complications.

Keywords: Tranexamic acid, lodopovidone, Pleurodesis, Pigtail catheter, Pleural effusion

\section{Background}

Pleural effusion is the most common manifestation of pleural diseases with different etiologies ranging from cardiopulmonary disorders to inflammatory or malignant diseases [1]. Lung and breast cancer account for $75 \%$ of malignant pleural effusions, and 10\% occurs with massive effusion with complete opacification of the hemi-thorax requiring urgent evaluation and treatment [2].

Chest tube thoracotomy is still the treatment of choice for pneumothorax and effusions [3], but it is considered an invasive procedure with potential morbidity and mortality thus the use of pigtail catheter can be considered [4].

Chemical pleurodesis is reported as the best treatment for recurrent pleural effusions when the underlying cause cannot be corrected. A large number of pleural irritants had been tried, but the research to detect the

* Correspondence: Adalex1970@yahoo.com

Faculty of Medicine, Tanta University, Foad Yousef Awes St. Bolkly, Alexandria, Egypt

\section{Springer Open}

ideal, effective, safe, inexpensive, and readily available agent for pleurodesis is still continuous. Talc is one of the most commonly used agents, as it is highly effective and widely available $[5,6]$. However, systemic embolization of talc has been reported, so there are serious concerns about its safety. Sclerosing agents such as tranexamic acid and iodopovidone were used for obliteration of the pleural cavity and cessation of the process of exudation. They are effective, safe, cheap, and readily available $[7,8]$.

\section{Aim of the work}

Evaluation of efficacy (success rate), safety (side effects), and tolerability of tranexamic acid and iodopovidone as chemical agents for pleurodesis, in the management of recurrent pleural effusion using pigtail catheter.

(c) The Author(s). 2020 Open Access This article is licensed under a Creative Commons Attribution 4.0 International License, which permits use, sharing, adaptation, distribution and reproduction in any medium or format, as long as you give appropriate credit to the original author(s) and the source, provide a link to the Creative Commons licence, and indicate if changes were made. The images or other third party material in this article are included in the article's Creative Commons licence, unless indicated otherwise in a credit line to the material. If material is not included in the article's Creative Commons licence and your intended use is not permitted by statutory regulation or exceeds the permitted use, you will need to obtain permission directly from the copyright holder. To view a copy of this licence, visit http://creativecommons.org/licenses/by/4.0/. 
Table 1 Comparison between the studied groups as regard the demographic data

\begin{tabular}{|c|c|c|c|c|c|c|}
\hline & \multicolumn{2}{|c|}{ Group I $(n=25)$} & \multicolumn{2}{|c|}{ Group II (n=25) } & \multirow{2}{*}{ Test of Sig. } & \multirow{2}{*}{$p$} \\
\hline & No. & $\%$ & No. & $\%$ & & \\
\hline $\begin{array}{l} \\
\text { Male } \\
\text { Female } \\
\text { Fex } \\
\end{array}$ & $\begin{array}{c}9 \\
16\end{array}$ & $\begin{array}{l}36.0 \\
64.0\end{array}$ & $\begin{array}{l}11 \\
14\end{array}$ & $\begin{array}{l}44.0 \\
56.0\end{array}$ & $\chi^{2}=0.333$ & 0.564 \\
\hline $\begin{array}{l}\text { Age } \\
\text { Min. }- \text { Max. } \\
\text { Mean } \pm \text { SD. } \\
\text { Median }\end{array}$ & \multicolumn{2}{|c|}{$\begin{array}{c}31.0-72.0 \\
55.68 \pm 11.14 \\
58.0\end{array}$} & \multicolumn{2}{|c|}{$\begin{array}{c}46.0-71.0 \\
59.80 \pm 7.70 \\
58.0\end{array}$} & $t=1.522$ & 0.136 \\
\hline
\end{tabular}

\section{Methods}

This prospective randomized study included 50 patients with unilateral recurrent pleural effusion of different etiologies divided into 2 equal groups.

Group I: Included 25 patients subjected to pleurodesis using tranexamic acid.

Group II: Included 25 patients subjected to pleurodesis using iodopovidone.

The study was done in Chest Department, Tanta University Hospital during the period from May 2016 to April 2017.

\section{Inclusion criteria}

Moderate to large amount of unilateral recurrent pleural effusion, cooperative patient, hemodynamic stability with no bleeding, or coagulation disorders.

\section{Exclusion criteria}

Complicated para-pneumonic effusions or frank empyema, patients with encysted pleural effusions.

\section{Method of the study}

All patients included in the study were subjected to complete history taking, general, and local examination, routine laboratory investigation, and diagnostic thoracocentesis, radiographic evaluation by plain chest X-rays (PA and lateral views), CT chest and chest ultrasound when needed, small-bore pigtail catheter was inserted percutaneously under local anesthesia, pleurodesis, once the pigtail in the pleural space drained $150 \mathrm{ml}$ or less per day with full lung expansion confirmed by chest X-ray, injection of pleurodesis solutions was done as follows:

Group I: 4 ampules (Kapron, Amoun Company) including $500 \mathrm{mg}$ tranexamic acid for each, diluted in 50 $\mathrm{ml}$ of normal saline solution, and $10 \mathrm{ml}$ of $2 \%$ lidocaine were injected intra-pleural via pigtail catheter [7].

Group II: $20 \mathrm{ml}$ of 10\% povidone iodine (Betadine, Mundi-pharma Company), diluted in $80 \mathrm{ml}$ of saline solution and $10 \mathrm{ml}$ of $2 \%$ lidocaine were injected intrapleural via pigtail catheter [8].

The catheter was clamped for $6 \mathrm{~h}$ during which the patient was turned in all directions, supine, prone, right, left lateral decubitus, and sitting position so pleurodesis solution came in contact with all pleural surfaces [8].

Complete response is defined as a symptomatic improvement of dyspnea with complete radiographic resolution of the pleural effusion, partial response as symptomatic improvement with radiological recurrence of pleural effusion that did not require additional thoracentesis treatment failure is defined as recurrent pleural effusion that required thoracentesis [9].

Follow up: The patients were followed up at 2 weeks intervals clinically and radiologically for 12 weeks

\section{Statistical analysis}

Data analysis using IBM SPSS software package (version 20)

Table $\mathbf{2}$ Comparison between the studied groups as regard the main presenting symptoms

\begin{tabular}{|c|c|c|c|c|c|c|}
\hline \multirow[t]{2}{*}{ symptoms } & \multicolumn{2}{|c|}{$\begin{array}{c}\text { Group I } \\
(n=25)\end{array}$} & \multicolumn{2}{|c|}{$\begin{array}{c}\text { Group II } \\
(n=25)\end{array}$} & \multirow[t]{2}{*}{$\chi^{2}$} & \multirow{2}{*}{ p } \\
\hline & No. & $\%$ & No. & $\%$ & & \\
\hline Dyspnea & 15 & 60.0 & 20 & 80.0 & 2.381 & 0.123 \\
\hline Pleuritic Chest Pain & 2 & 8.0 & 1 & 4.0 & 0.355 & $\mathrm{FE}_{\mathrm{p}}=1.000$ \\
\hline Both & 8 & 32.0 & 4 & 16.0 & 1.754 & 0.185 \\
\hline
\end{tabular}


Table 3 Comparison between the studied groups as regard the side effusion

\begin{tabular}{|c|c|c|c|c|c|c|}
\hline \multirow[t]{2}{*}{ Side } & \multicolumn{2}{|c|}{$\begin{array}{c}\text { Group I } \\
(\mathbf{n}=\mathbf{2 5})\end{array}$} & \multicolumn{2}{|c|}{$\begin{array}{c}\text { Group II } \\
(\mathbf{n}=\mathbf{2 5})\end{array}$} & \multirow[t]{2}{*}{$\chi^{2}$} & \multirow{2}{*}{ P } \\
\hline & No. & $\%$ & No. & $\%$ & & \\
\hline Right & 16 & 64.0 & 18 & 72.0 & 00 & -1 \\
\hline Left & 9 & 36.0 & 7 & 28.0 & 0.500 & 0.244 \\
\hline
\end{tabular}

\section{Results}

The mean age of patients in group I was $55.68 \pm 11.14$ years, and in group II was of $59.80 \pm 7.70$ years with no statistically significant difference (Table 1 ).

Dyspnea and chest pain were the common complaint. The majority of effusions were right sided $(64.0 \%$ in group I) and (72.0\% in group II). Three mesothelioma patients were non-dyspneic but suffer from severe agonizing chest pain requiring pleurodesis (Tables 2 and 3). The underlying pathologies of pleural effusion in the studied groups revealed that 24 patients had pleural effusion due to isolated hepatic hydrothorax without ascites or with mild ascites (10 in group I and 14 in group II), and 26 patients had malignant pleural effusion (15 in group I and 11 in group II). Metastatic breast cancer was the commonest cause of malignant pleural effusion followed by metastatic lung cancer and metastatic ovarian carcinoma (Table 4).

Regarding the size of the pigtail catheter used in research, significant increase in favor to the 12 French sizes in each group (96\% in group I and $84 \%$ in group II ) (Table 5).

There were no significant differences between the 2 studied groups as regards to the period of placement of pigtail catheter prior to as well as after pleurodesis (Table 6).

The final follow-up of pleurodesis in both groups showed that the success rate was more in group I than group II ( $88.0 \%$ vs $76.0 \%)$ (Table 7 ).

Minor complications were founded with tranexamic acid pleurodesis as hypotension in $12 \%$, pleuritic chest pain in $8 \%$, shock and fever in $4 \%$. While in iodopovidone pleurodesis, pleuritic chest pain in $12 \%$, hypotension in $8 \%$, empyema, fever, and shock in $4 \%$ (Table 8).

\section{Discussion}

Management of recurrent pleural effusions is considered one of the most difficult medical problems. Symptoms are caused by fluid which re-accumulates rapidly after

Table 4 Comparison between the studied groups as regard the underlying pathology

\begin{tabular}{|c|c|c|c|c|c|c|}
\hline & \multicolumn{2}{|c|}{$\begin{array}{c}\text { Group I } \\
(n=25)\end{array}$} & \multicolumn{2}{|c|}{$\begin{array}{c}\text { Group II } \\
(\mathrm{n}=\mathbf{2 5})\end{array}$} & \multirow[t]{2}{*}{$\chi^{2}$} & \multirow[t]{2}{*}{$\mathbf{p}$} \\
\hline & No. & $\%$ & No. & $\%$ & & \\
\hline $\begin{array}{l}\text { The Underlying Pathology } \\
\text { Hepatic hydrothorax } \\
\text { Malignant }\end{array}$ & $\begin{array}{l}10 \\
15\end{array}$ & $\begin{array}{l}40.0 \\
60.0\end{array}$ & $\begin{array}{l}14 \\
11\end{array}$ & $\begin{array}{l}56.0 \\
44.0\end{array}$ & 1.282 & 0.258 \\
\hline $\begin{array}{l}\text { Metastatic breast } \\
\text { cancer }\end{array}$ & 3 & 12.0 & 6 & 24.0 & 1.220 & $\mathrm{FE}_{\mathrm{p}}=0.463$ \\
\hline $\begin{array}{l}\text { Malignant } \\
\text { pleural } \\
\text { mesothelioma }\end{array}$ & 3 & 12.0 & 1 & 4.0 & 1.087 & ${ }^{F E} \mathrm{p}=0.609$ \\
\hline $\begin{array}{l}>\text { Metastatic ovarian } \\
\text { tumors }\end{array}$ & 4 & 16.0 & 1 & 4.0 & 2.000 & $\mathrm{FE}_{\mathrm{p}}=0.349$ \\
\hline $\begin{array}{l}>\text { Metastatic lung } \\
\text { cancer }\end{array}$ & 3 & 12.0 & 2 & 8.0 & 0.014 & FEp $=1.000$ \\
\hline $\begin{array}{l}>\text { Other } \\
\text { malignancies }\end{array}$ & 2 & 8.0 & 1 & 4.0 & 0.355 & FEp $=1.000$ \\
\hline
\end{tabular}


Table 5 Comparison between the groups as regard the size of the pigtail catheter used

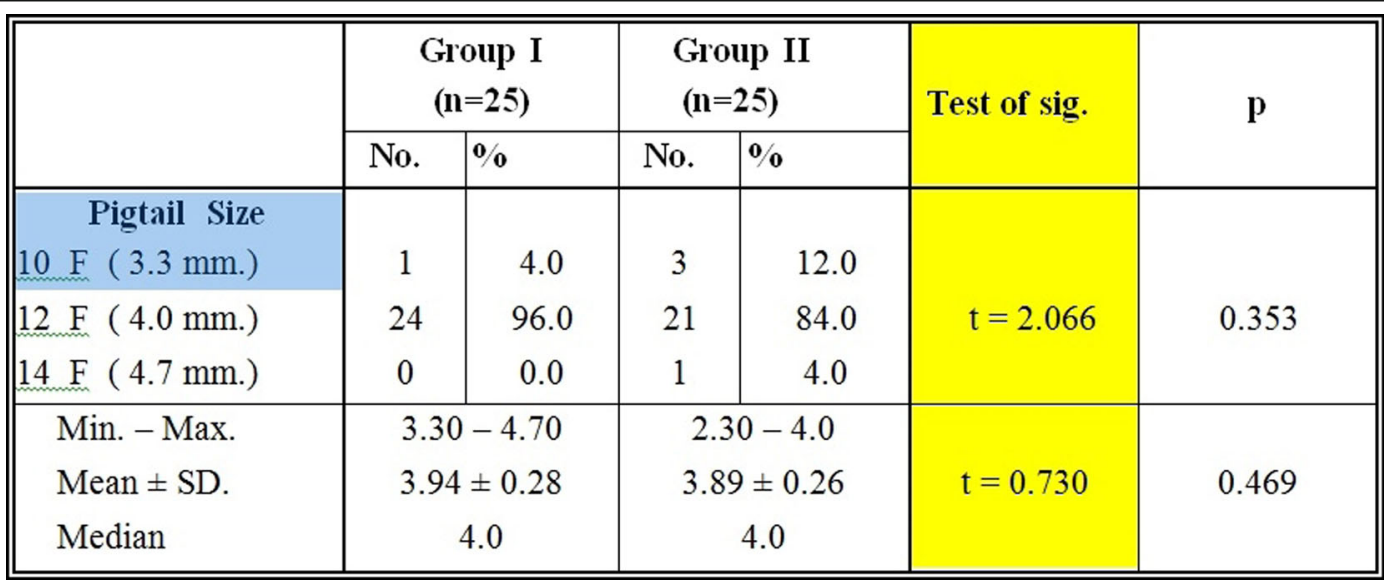

aspiration [10]. Survival of patients with malignant pleural effusion may extend for months or even years. Therefore, the aim of treatment should be directed to relieve the distress and improve the quality of life of those patients besides the management of the primary disease [7].

The repeated aspiration to relieve dyspnea is both physically and psychologically traumatic to the patient and burden to the physician, so a more definitive management strategy must be undertaken to solve this problem, this strategy included tube thoracotomy, insertion of pleural catheter with or without pleurodesis, medical thoracoscopy, or video-assisted thoracoscopic surgery with pleurodesis [11].

Chemical pleurodesis is one of the most accepted treatments for recurrent pleural effusions. The choice of the best sclerosing agent, which is determined by the efficacy, safety, accessibility of the agent, its cost, ease of administration, and the number of administrations to achieve complete response [12].

In the present study, 50 patients were subjected to thorough investigations and they were classified into 2 equal groups 25 patients for each. The origin of effusion in group I was malignant pleural effusion in 15 patients (60\%) and hepatic hydrothorax in 10 patients (40\%), and in group II was malignant pleural effusion in 11 patients (44\%) and hepatic hydrothorax in 14 patients (56\%) as seen in Table 4. Hepatic hydrothorax as well as malignant pleural effusion is recurrent and rapidly accumulative, so many clinicians are convinced to place indwelling pleural catheters (IPCs) for non-malignant effusions like hepatic hydrothorax, sometimes spontaneous mechanical pleurodesis occurs, sometimes chemical pleurodesis with sclerosing agent is needed [13-20].

In this study, as regard the size of pigtail catheter, different diameters were used $(10 \mathrm{~F}, 12 \mathrm{~F}$, and $14 \mathrm{~F})$ with a

Table 6 Comparison between the studied groups regarding duration of pigtail catheter placement before, and after pleurodesis

\begin{tabular}{|c|c|c|c|c|}
\hline & $\begin{array}{c}\text { Group I } \\
(n=25)\end{array}$ & $\begin{array}{c}\text { Group II } \\
(n=25)\end{array}$ & $t$ & $p$ \\
\hline $\begin{array}{l}\text { Duration of Placement } \\
\text { of Pigtail before Pleurodesis } \\
\text { Min. - Max. } \\
\text { Mean }=\mathrm{SD} \text {. } \\
\text { Median }\end{array}$ & $\begin{array}{c}7.0-20.0 \\
14.36 \pm 4.79 \\
14.0\end{array}$ & $\begin{array}{c}9.0-25.0 \\
15.84=4.14 \\
15.0\end{array}$ & 1.169 & 0.248 \\
\hline $\begin{array}{l}\text { Duration of Placement of } \\
\text { Pigtail After Pleurodesis } \\
\text { Min. - Max. } \\
\text { Mean }=\mathrm{SD} \text {. } \\
\text { Median }\end{array}$ & $\begin{array}{c}1.0-2.0 \\
1.20=0.41 \\
1.0\end{array}$ & $\begin{array}{c}1.0-1.0 \\
1.0=0.0 \\
1.0\end{array}$ & 2.242 & 0.25 \\
\hline
\end{tabular}


Table 7 Comparison of the final follow up (after 12 weeks) of the different studied groups

\begin{tabular}{|c|c|c|c|c|c|c|}
\hline & \multicolumn{2}{|c|}{$\begin{array}{l}\text { Group I } \\
(n=25)\end{array}$} & \multicolumn{2}{|c|}{$\begin{array}{l}\text { Group II } \\
\qquad(\mathrm{n}=25)\end{array}$} & \multirow[t]{2}{*}{$\chi^{2}$} & \multirow[t]{2}{*}{$\mathrm{p}$} \\
\hline & No. & $\%$ & No. & $\%$ & & \\
\hline Final follow up results & & & & & & \\
\hline Success & 22 & 88.0 & 19 & 76.0 & & \\
\hline Failure & 3 & 12.0 & 6 & 24.0 & & \\
\hline
\end{tabular}

significant increase in favor to the 12 French sizes in each group (96\% in group I and $84 \%$ in group II) as seen in Table 5. This size was the most available in market at the time of the research.

Shoji $\mathrm{T}$ et al. [11] continue to support the use of small-bore chest drainage and sclerotherapy, although there was no significant difference between large and small-bore catheter. Agarwal et al. [8] and Aziz et al. [21] concluded that the use of standard size pigtail catheters $(8.5 \mathrm{~F})$ is usually very successful in draining the pleural fluid, less time consumption, lower cost, and bedside technique makes it superior to the conventional chest tube.

In our study, pleurodesis was performed when the daily drainage volume was less than $150 \mathrm{ml} /$ day, X-ray chest was done to make sure that no pleural fluid was left and the underlying lung was re-expanded. In accordance to our research, Martinez et al. [22] mentioned that pleurodesis is performed after radiographical confirmation of complete lung re-expansion. Also Shoji $\mathrm{T}$ et al. [11] made pleurodesis when chest tube fluid drainage decreased to less than $150 \mathrm{ml} /$ day and the lung was fully re-expanded on chest X-ray.

In this study, as regard days of placement of pigtail after pleurodesis, the mean durations of the inserted tube post pleurodesis were 1.20 in group I, and 1.0 in group II, as seen in Table 6. Heffner et al. [23] showed that the chest tubes were removed from most patients when drainage of pleural fluid decreased to less than $100 \mathrm{ml} /$ day after pleurodesis. In other patients, the chest tube was routinely removed several hours after instillation of doxycyline. Tomlinson and Sahn [24] said that the chest drain is usually left in position for 24-72 h, but it may be left longer if the drainage of fluid continues.

On a search for the cheapest and most available sclerosing agent with the least side effects, the present study aimed to evaluate the effectiveness of tranexamic acid and iodopovidone as chemical agents for pleurodesis in recurrent pleural effusion.

In group 1, we used 4 ampules (2000 mg of tranexamic acid) for each patient and the patients were followed up at 2 weeks intervals for 12 weeks, 22 patients showed complete response with a success rate of $88 \%$, and 3 patients (12\%) show failure of pleurodesis, the first case was malignant mesothelioma which failed due to failure of lung expansion and thickening of the pleura as shown by CT chest, and the other two cases were hepatic hydrothorax (Figs. 1 and 2).

The success rate in the present study was higher than Eman et al. [25] study, as they achieved a success rate of $73.5 \%$, but lower than EL-Bouhi et al. [7], as the success rate was $90 \%$, their higher success rate may be due to higher dose used which was 10 ampoules $(5000 \mathrm{mg}$ of tranexamic acid).

The results in the present study were higher than the results of most of the other studies that use other chemical agent for pleurodesis. For example, Zimmer et al. [26] found a success rate of $65 \%$ on using bleomycin for pleurodesis, and Martínez et al. [22] achieved a success rate of $60-80 \%$ on using tetracycline for pleurodesis.

Table 8 Comparison between the groups as regard complications of pleurodesis

\begin{tabular}{||l|c|c|c|c|c|c||}
\hline \multirow{2}{*}{ Pleurodesis complications } & \multicolumn{2}{|c|}{ Group I (n=25) } & \multicolumn{2}{|c|}{ Group II (n=25) } & \multirow{2}{*}{$*^{2}$} & \multirow{2}{*}{ FEp } \\
\cline { 2 - 6 } & No. & $\%$ & No. & $\%$ & & \\
\hline$>$ Fever & 1 & 4.0 & 1 & 4.0 & 0.0 & 1.000 \\
\hline$>$ Pain & 2 & 8.0 & 3 & 12.0 & 0.222 & 1.000 \\
\hline$>$ Empyema & 0 & 0.0 & 1 & 4.0 & 1.020 & 1.000 \\
\hline$>$ Hypotention & 3 & 12.0 & 2 & 8.0 & 0.222 & 1.000 \\
\hline$>$ Shock & 1 & 4.0 & 1 & 4.0 & 0.0 & 1.0000 \\
\hline
\end{tabular}




\section{Case number1:}
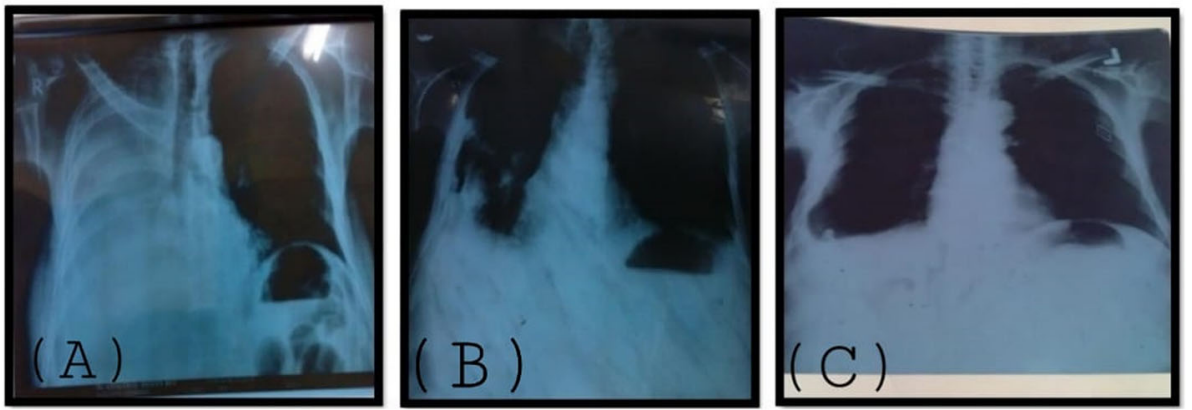

Fig. 1 a Plain chest X-ray PA view showing massive right-sided pleural effusion before drainage. b Plain chest X-ray PA view showing evacuation of the effusion with the pigtail pleural catheter seen in place. c Plain chest X-ray PA view showing complete evacuation of the effusion after pleurodesis by iodopovidone (case 1)

In our study, minor complications were founded with tranexamic acid pleurodesis as seen in Table 8 as hypotension in $12 \%$, pleuritic chest pain in $8 \%$, shock and fever in $4 \%$.

In a study done by Bediwy and Galal [27], who investigated pigtail catheter insertion for draining pleural effusions of different etiologies. They evaluated success and complications of pigtail catheter insertion in 51 cases of pleural effusion. They recorded complications including chest pain at the site of insertion requiring analgesia (45.09), pneumothorax (19.6), blockade of the catheter (3.92), and infection (1.96). Blockade of the catheters and infection were associated with procedure failure.

The reported complications with different sclerosing agents are chest pain, fever, and cough, as seen in Janssen et al. [28].

In group II, we used $20 \mathrm{ml}$ of $10 \%$ povidone iodine, diluted in $80 \mathrm{ml}$ of saline solution and $10 \mathrm{ml}$ of debocaine $2 \%$. Regarding the doses of the pleurodetic agent, our study agreed with Agarwal et al. [8], who recommended the utilization of $20 \mathrm{ml}$ of $10 \%$ iodo-povidone mixed with $80 \mathrm{ml}$ normal saline solution.

In our study, the patients were followed up for 12 weeks, 19 patients showed complete response, (the success rate 76\%), and 6 patients show failure of pleurodesis (24\%). The causes of failure in the first case were due to secondary bacterial infection and empyema, and intercostal tube was inserted via thoracoscope to drain the pus from the pleural space. Two cases were hepatic hydrothorax which failed due to massive transudative effusion due to loss of protein and fluid accumulate rapidly, one case showed accidental dislodgment of pigtail catheter, and two cases were malignant effusion.

These results were consistent with those of Carlos and his colleagues [29], who found that iodopovidone is one of the best sclerosing agents in recurrent effusions regardless the etiology, as it is effective, safe, inexpensive, and readily available. In 2004, Shaw and Agarwal [30] meta-analysis observational studies on the success rate and safety of chemical pleurodesis using iodopovidone

\section{Case number2:}
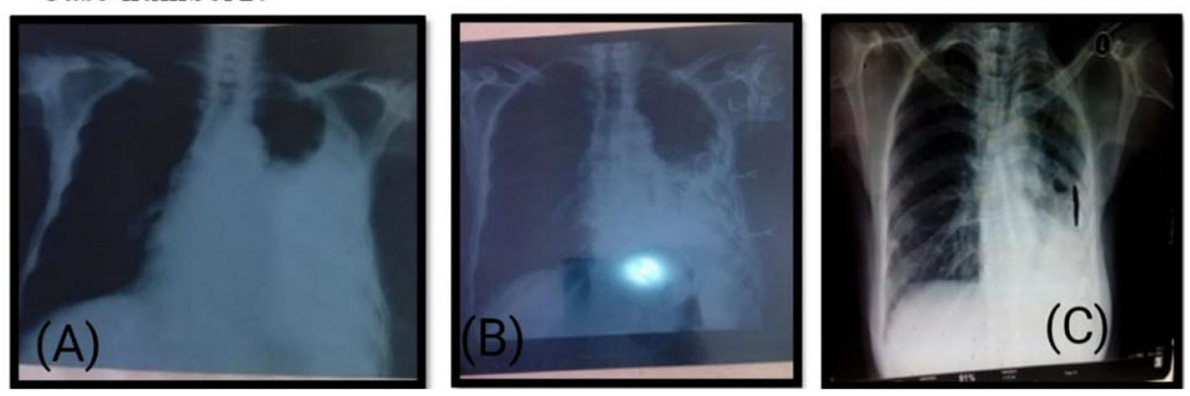

Fig. 2 a Plain chest X-ray PA view showing massive left-sided pleural effusion before drainage. b Plain chest X-ray PA view showing evacuation of the effusion with the pigtail pleural catheter seen in place. c Plain chest X-ray PA view showing complete evacuation of the effusion after pleurodesis by tranexamic acid (case 2) 
revealed that its success rate ranged from 64.2 to $100 \%$, with an overall success rate of $90.6 \%$.

These results agreed with those of Ritesh et al. [31] who studied efficacy and safety of iodopovidone as a chemical pleurodesis for variety of indications in 256 patients, which included pleural effusions (157 patients), and pneumothorax (108 patients). The pleural effusions were mainly malignant effusions, and the pneumothorax was spontaneous, both primary (where the underlying lung is healthy) and secondary (where the pneumothorax occurs as a complication of some underlying pulmonary disease). There were no deaths related to chemical pleurodesis with iodopovidone.

Our results were consistent with those studies done by Dey et al. [32], who studied 38 patients with symptomatic malignant or recurrent pleural effusion and pneumothorax, had pleurodesis using iodopovidone. A complete response with no recurrence during follow-up was obtained in 34 patients (89.5\%), and failure in 4 cases $(10.5 \%)$ all failed cases had malignant pleural effusion.

In this work, minor complications were founded in iodopovidone pleurodesis as pleuritic chest pain (12\%), hypotention (8\%), empyema, fever and shock (4\%), as seen in Table 8.

In a study done by Mohsen et al. [33] to compare the success, safety, and outcome of thoracoscopic talc poudrage (TTP) versus povidone iodine pleurodesis (PIP) through a thoracostomy tube in management of malignant pleural effusion due to metastatic breast cancer. Twenty-two received talc poudrage and 20 patients received pleurodesis by instilling povidone iodine through a thoracostomy tube. Talc was associated with severe pleuritic chest pain, fever, and longer hospital stay. Both groups achieved good symptom control.

Das et al. [34] reported that povidone iodine is equally effective and safe as talc, and may be preferred because of easy availability, low cost, and it can be used for recurrent pleural effusions. While in Helmy et al. [35] study, 20 patients with hepatic hydrothorax had pleurodesis using povoiodine in 8 patients, vibramycin in 6 patients, and talc slurry in other 6 patients. The outcome revealed that chemical pleurodesis was effective in the treatment of hepatic hydrothorax in $15 / 20$ patients (75\%), the success rate was $87.5 \%$ in patients treated by iodopovidone, $66.7 \%$ in vibramycin, and $66.7 \%$ in patients treated with talc slurry. However, a single case treated by talc slurry died of hepatocellular insufficiency 14 days following the procedure.

\section{Conclusions}

We concluded that tranexamic acid and iodopovidone were found to be an effective alternative agent for pleurodesis with low cost and minimal complications.
We recommend wider use of these cheap sclerosing agents instead of the costly one with the same results.

\section{Acknowledgements}

Not applicable.

\section{Authors' contributions}

AHA was responsible for study design and final revision ASE shared in study design and was responsible for the practical part of the research, selection of cases, data collection and statistics, manuscript preparation, editing, and reviewing. All authors have read and approved the manuscript.

\section{Funding}

This study had no funding from any resource.

\section{Availability of data and materials}

All data generated or analyzed during this study are included in this published article [and its supplementary information files].

\section{Ethics approval and consent to participate}

The study protocol was approved from the research ethics committee of the Faculty of Medicine, Tanta University, with reference number (13532). A written consent form was obtained from every patient to participate in the research work after sufficient explanation before initiating the study.

\section{Consent for publication}

All participated patients signed an informed written consent form to publish the data with respect to the privacy of patients and confidentiality of the data as patients' names were replaced by code numbers to confirm their privacy and the results of the study were used only for scientific purpose.

\section{Competing interests}

The authors declare that they have no competing interests.

Received: 13 May 2020 Accepted: 15 July 2020

Published online: 31 July 2020

References

1. Diaz-Guzman E, Dweik RA (2007) Diagnosis and management of pleural effusions: a practical approach. ComprTher 33(4):237-246

2. Khaleeq G, Musani Al (2008 Jul) Emerging paradigms in the management of malignant pleural effusions. Respir Med 102(7):939-948

3. Munnell ER (1997) Thoracic drainage. Annals of Thoracic Surgery 63(5):14971502

4. Roberts JS, Bratton SL (1998 Oct) and BroganTV. Efficacy and complications of percutaneous pigtail catheters for thoracostomy in pediatric patients. Chest 114(4):1116-1121

5. Kalomenidis I (2011 Oct) Beyond talc pleurodesis: do we really need new methods? Respirology 16(7):1020-1022

6. Diacon AH, Wyser C, Bolliger CT, Tamm M, Pless M, Perruchoud AP et al (2000) Prospective randomized comparison of thoracoscopic talc poudrage under local anesthesia versus bleomycin instillation for pleurodesis in malignant pleural effusions. Am J Respir Crit Care Med 162:1445-1449

7. El-Bouhi M, El-Naggar T, Mansour M (2000) Pleurodesis with tranexamic acid. The Egyptian Journal of Chest Diseaes and Tuberculosis. 49:15-18

8. Agarwal R, Aggarwal AN, Gupta D (2006) Efficacy and safety of iodopovidone pleurodesis through tube thoracostomy. Respirology. 11(1): 105-108

9. Stefani A, Natali P, Casali C, Morandi U (2006) Talc poudrage versus talc slurry in the treatment of malignant pleural effusion. A prospective comparative study. Eur J Cardiothorac Surg 30(6):827-832

10. Lee YC, Baumann MH, Maskell NA, Waterer GW, Eaton TE, Davies RJ et al (2003) Pleurodesis practice for malignant pleural effusions in five Englishspeaking countries. Chest 124(6):2229-2238

11. Shoji T, Tanaka F, Yanagihara K, Inui K, Wada H (2002) Phase II study of repeated intrapleural chemotherapy using implantable access system for management of malignant pleural effusion. Chest 121(3):821-824

12. Walker Renad PB, Vaughan LM, Sahn SA (1994) Chemical pleurodesis for treatment of malignant pleural effusions. Ann Intern Med 120(1):56-64 
13. Goergen N, Strickland J, Buchan K (2019) Decompressive talc pleurodesis for hepatic hydrothorax. Br J Hosp Med (Lond) 80(8):480-481

14. Hou F, Qi X, Guo X (2016 Nov) Effectiveness and safety of pleurodesis for hepatic hydrothorax: a systematic review and meta-analysis. Dig Dis Sci 61(11):3321-3334

15. Chaaban T, Kanj N, Bou Al (2019 Aug) Hepatic hydrothorax: an updated review on a challenging disease. Lung. 197(4):399-405

16. Ortega Quiroz RJ, Moscote Granadillo M, Díaz Hernández A, Spath Spath A, Rodríguez María R, Reyes Romero A et al (2019) Hepatic hydrothorax: presentation of 3 cases with different therapeutic approaches. Rev Gastroenterol Peru. 39(1):64-69

17. Aboudara M, Maldonado F. Indwelling pleural catheters for benign pleural effusions: what is the evidence? .Curr Opin Pulm Med. 2019 Jul;25(4):369373.Baig

18. MA MMB, Attar BM, Khan Z, Demetria M, Gandhi SR (2018 Aug 6) Efficacy and safety of indwelling pleural catheters in management of hepatic hydrothorax: a systematic review of literature. Cureus 10(8):e3110

19. Shojaee S, Rahman N, Haas K, Kern R, Leise M, Alnijoumi M et al (2019 Mar) Indwelling tunneled pleural catheters for refractory hepatic hydrothorax in patients with cirrhosis: a multicenter study. Chest. 155(3):546-553

20. Sharaf-Eldin M, Bediwy AS, Kobtan A, Abd-Elsalam S, El-Kalla F, Mansour L et al (2016) Pigtail catheter: a less invasive option for pleural drainage in Egyptian patients with recurrent hepatic hydrothorax. Gastroenterol Res Pract:4013052

21. Aziz F, Penupolu S, Flores D (2012) Efficacy of percutaneous pigtail catheters for thoracostomy at bedside. J Thorac Dis. 4(3):292-295

22. Martínez-Moragón E, Aparicio J, Rogado MC, Sanchis J, Sanchis F, Gil-Suay V (1997) Pleurodesis in malignant pleural effusions: a randomized study of tetracycline versus bleomycin. Eur Respir J 10(10):2380-2383

23. Heffner JE, Standerfer RJ, Torstveit J, Unruh L (1994) Clinical efficacy of doxycycline for pleurodesis. CHEST 105(6):1743-1747

24. Tomlinson JR, Sahn SA (2009) Treatment of pleural effusion. Chest 89(3): 470-477

25. Mohammed E, Eisa S, Abdelghaffar N (2015) Efficacy of tranexamic acid as pleurodesis agent in malignant pleural effusion. Egyptian Journal of Chest Diseases and Tuberculosis 64(3):587-591

26. Zimmer PW, Hill M, Casey K, Harvey E, Low DE (1997) Prospective randomized trial of talc slurry versus bleomycin in pleurodesis for symptomatic malignant pleural effusions. Chest 112(2):430-443

27. Bediwy AS, Galal HA (2012) Pigtail catheter use for draining pleural effusions of various etiologies. Pulmonolgy 12:6-12

28. Janssen JP, Collier G, Astoul P, Tassi GF, Noppen M, Rodriguez-Panadero F et al (2007) Safety of pleurodesis with talc poudrage in malignant pleural effusion: a prospective cohort study. Lancet 369(9572):1535-1539

29. Carlos A, Rafael L, Alberto R (2003 April) lodopovidone pleurodesis for recurrent pleural effusions. Chest 123:1318-1319

30. Shaw P, Agarwal R (2004) Pleurodesis for malignant pleural effusions. Cochrane Database Sys Rev 1:CD002916

31. Ritesh Agarwal, Aggarwal AN, Gupta D, and Jindal SK: Efficacy and safety of iodopovidone in chemical pleurodes Chest 2006; 100(11) 2043-7.

32. Dey A, Bhuniya S, Datta Chaudhuri A, Pandit S, Saha-Dutta CM, Sengupta A, Saha I (2010) lodopovidone pleurodesis: experience of a tertiary hospital in Kolkata. Singapore Med J 51(2):163-165

33. Mohsen TA, Zeid A, Meshref M, Tawfeek N, Redmond K, Ananiadou OG (2011) Local iodine pleurodesis versus thoracoscopic talc insufflation in recurrent malignant pleural effusion: a prospective randomized control trial. Eur J. CardiothoracSurg 40(2):282-286

34. Das SK, Saha SK, Das A, Halder AK, Banerjee SN, Chakraborty M (2008) A study of comparison of efficacy and safety of talc and iodopovidone for pleurodesis of malignant pleural effusions. J. Indian Med Assoc. 106(9):590-592

35. Helmy N, Akl Y, Kaddah S, Hafiz HA, Makhzangy HE (2010) Egyptian experience in using chemical pleurodesis as an alternative management in refractory hepatic hydrothorax. Arch Med Sci. 6(3):336-342

\section{Publisher's Note}

Springer Nature remains neutral with regard to jurisdictional claims in published maps and institutional affiliations.

\section{Submit your manuscript to a SpringerOpen ${ }^{\circ}$ journal and benefit from:}

- Convenient online submission

- Rigorous peer review

- Open access: articles freely available online

- High visibility within the field

- Retaining the copyright to your article

Submit your next manuscript at $\boldsymbol{\nabla}$ springeropen.com 